\title{
LED Nightlight Infringement Case
}

\section{Andy Chan ${ }^{*}$}

Law firm, China Confaith Intellectual Property Agency Co., Ltd, Shantou City, Guanddong Province, China

*Corresponding author: Andy Chan, Law firm, China Confaith Intellectual Property Agency Co., Ltd, Shantou City, Guanddong Province, China; Tel: 8613502957234, 8675488486227; E-mail: chinaconfaith@gmail.com

Rec date: Apr 7, 2014; Acc date: Apr 23, 2014; Pub date: Apr 30, 2014

Copyright: (C) 2014 Chan A, This is an open-access article distributed under the terms of the Creative Commons Attribution License, which permits unrestricted use, distribution, and reproduction in any medium, provided the original author and source are credited.

\section{Case Report}

In June 2013, the patentee Mr. Wen consult us that, his patent product, patent number: 201230103617.8, named "LED nightlight (mushroom)" was sold in Foshan, Yulin and so on and he found that many other manufacturers and businesses copied and sold it. He felt very worry that his products were infringed and market sales was much lower. After consulting related law, Mr. Wen consign us to protect his patent and supply us patent license, invoice from SIOP and patent evaluation report about "LED nightlight (mushroom)".

In July 2013, the employees from our company go to market in Yulin and Foshan to search. The result is the same as the information provided by Mr. Wen. There are many copied "LED nightlight (mushroom)" sold there and many of them are from Chaoshan factories. Based on this situation, we cooperated with local notarized Department and bought the above evidence from 8 infringing shops and got information about business license and person. In August 2013, we send "The lawyer warning letter" to the above infringing shops and manufacturers respectively. But they ignored it and didn't reply it on time. Then Mr. Wen had to institute court action with Shantou City.

Intermediate People's court against the electronic manufacturer located in Chaozhou City and the Yulin shop owner "Peng". At the same time, we send administrative lawsuit to Foshan City Intellectual Property Bureau through Shantou City Bureau of intellectual property rights service center against the certain electric company and the store located in Foshan. Requesting Mr. Ma from Foshan electric company, Mr. Chen from Foshan store who is the above accused person to stop infringing and compensate for Mr. Wen's loss.

Shantou City Intermediate People's court accepted and heard this case. They arranged out-of-court settlement between Mr. Wen and the Chaozhou city electronic factory many times. At the beginning, the electronic factory said that they didn't produce it directly. They bought semi-manufactured appearance design goods from the factory in Jieyang and assembled and sold it to the customers. They felt that they didn't manufacture and infringe patent product from $\mathrm{Mr}$. Wen subjectively and there is a visual difference between the design on their product and the patent product and argued that, the amount of infringing products is about more than 100 pcs. So even they are charged infringement successfully and it can compensate enough for the patentee's requesting loss. The presiding judge said that, the package of the infringing products has been printed the accused factory and address, which is different with the reason that the accused factory didn't produce it directly. At last, after persuasion of the presiding judge and compromise of the patentee, the Chaozhou electric factory and Mr. Peng agreed to stop manufacturing and selling infringing products and compensated for the patentee's filing case fee and signed dispute settlement. So far, we won this rights protection case.

Besides, in 2 September, Foshan Intellectual Property Bureau hold oral hearing against accused products. 